\title{
ANALISIS ALAT PENANGKAP IKAN BERBASIS CODE OF CONDUCT FOR RESPONSIBLE FISHERIES (CCRF) DI TEMPAT PELELANGAN IKAN (TPI) TAWANG, KENDAL
}

\author{
Analysis of Fishing Gears Based on Code of Conduct for Responsible Fisheries (CCRF) at \\ Tawang Fish Auction, Kendal \\ Ihtisyamul Firdaus, Aristi Dian Purnama Fitri, Sardiyatmo dan Faik Kurohman \\ Program Studi Pemanfaatan Sumberdaya Perikanan, Jurusan Perikanan \\ Fakultas Perikanan dan Ilmu Kelautan, Universitas Diponegoro \\ Jl. Prof. Soedarto, SH Tembalang, Semarang \\ Email : ihtisyamulfirdaus@yahoo.com, dan aristidian.undip@gmail.com
}

Diserahkan tanggal 20 Juli 2017, Diterima tanggal 15 Agustus 2017

\begin{abstract}
ABSTRAK
Pengelolaan sumberdaya ikan sangat erat kaitannya dengan pengelolaan operasi penangkapan ikan dan sasaran penangkapan ikan yang dilakukan. Perkembangan kegiatan penangkapan ikan di dunia terus meningkat dan telah menunjukkan gejala overfishing salah satunya di perairan TPI Tawang. Alat penangkap ikan yang ada di Tempat Pelelangan Ikan (TPI) Tawang adalah alat tangkap pasif (gill net, trammel net, dan trap) dan aktif (purse seine waring, mini trawl dan boat seine). Tujuan penelitian ini adalah menganalisis unit penangkapan yang sesuai dengan Code of Conduct Responsible for Fisheries (CCRF) di TPI Tawang, Kendal. Metode penelitian yang digunakan adalah metode deskriptif dengan teknik sampling quota sampling, pada bulan Maret-April 2017. Rentang nilai 4 kategori alat tangkap ramah lingkungan, yaitu nilai 1 - 9 diaktegorikan sangat tidak ramah lingkungan, nilai 10 - 18 dikategorikan tidak ramah lingkungan, nilai 19 - 27 dikategorikan ramah lingkungan, dan nilai 28 - 36 dikategorikan sangat ramah lingkungan. Hasil yang dipereroleh dari penelitian ini yaitu alat tangkap yang masuk kategori sangat ramah lingkungan di TPI Tawang adalah gill net, trammel net dan trap dengan masing-masing nilai 32,8; 32,4 dan 34,1 sedangkan boat seine dan purse seine waring termasuk alat tangkap ramah lingkungan dengan masing-masing nilai 25,1 dan 22,9. Alat tangkap mini trawl termasuk alat tangkap yang tidak ramah lingkungan dengan nilai 15,3.
\end{abstract}

Kata kunci: Analisis Alat Penangkap Ikan, Code of Conduct of Responsible Fisheries (CCRF), TPI Tawang

\section{ABSTRACT}

The management of fish resources is closely related to manage of fishing operations and fishing targets. According to WWF (2013), the development of world fishing activities continues to increase and has shown overfishing one of them in Tawang Fishing Auction Place. Fishing equipment in Tawang Fishing Auction House is Gill net, Trammel net, Purse Seine type Waring, Trap, Small Bottom Trawl and Boat Seine. The fishing gear has 2 kinds of the operation that was passive and active catching tool. The purpose of this study is to analyze fishing gear unit according to the Code of Conduct Responsible fisheries in Tawang Fishing Auction House, Kendal. The method used in this research is descriptive method with quota sampling technique, in March-April 2017. Data collection is done by interview to fisherman and direct observation in the field. Range of values of 4 categories of environmentally friendly gear tools as follows: 1- 9 were not very environmentally friendly, 10 - 18 is not environmentally friendly, 19 - 27 environmentally friendly, 28 - 36 is very environmentally friendly. The results obtained from this research are fishing gear that is categorized as very environmentally friendly in Tawang Fishing Auction House is Gill net, Trammel net and Trap with each score 32.8 ; 32.4 and 34.1 while Boat Seine and Purse Seine type Waring are environmentally friendly fishing gear with each score 25.1 and 22.9. Meanwhile, Mini Trawl including fishing gear that not environmentally friendly with score 15.3.

Keywords: Analysis of fishing gear, Code of Conduct of Responsible Fisheries (CCRF), Tawang Fish Auction

\section{PENDAHULUAN}

Wilayah perikanan tangkap Kabupaten Kendal meliputi wilayah perairan Pantai Utara Jawa membentang sepanjang \pm 42,4 km yang mencakup 7 Wilayah Kecamatan yakni :
Kecamatan Kaliwungu, Kecamatan Brangsong, Kecamatan Kendal, Kecamatan Patebon, Kecamatan Cepiring, Kecamatan Kangkung dan Kecamatan Rowosari (Dinas Kelautan dan Perikanan Kabupaten Kendal, 2012 dalam Wismaningrum et al., 2013). Jumlah produksi di Kabupaten Kendal sebesar

C Copyright by Saintek Perikanan (Indonesian Journal of Fisheries Science and Technology), ISSN : 1858-4748 
$1.811,0$ ton dengan nilai produksi sebesar Rp.10.616.840.000,00. dari 4 TPI, yaitu TPI Tawang, TPI Sendang Sikucing, TPI Tanggul Malang dan TPI Bandengan (Badan Pusat Statistik Provinsi Jawa Tengah, 2013).

Menurut Nanholy (2013), perkembangan kegiatan penangkapan ikan dunia terus meningkat dan telah menunjukkan gejala overfishing di beberapa bagian perairan dunia. Penangkapan secara berlebihan menjadi masalah, karena lebih dari $80 \%$ stok ikan di dunia mengalami eksploitasi berlebihan. CCRF (Code of Conduct Responsible Fisheries) dipergunakan sebagai pedoman pelaksanaan kegiatan perikanan secara bertanggung jawab. Pedoman ini memberi kelengkapan bagi upaya nasional dan internasional untuk menjamin pemanfaatan sumberdaya laut yang lestari dan berkelanjutan (Sumardi et al., 2014).

TPI Tawang merupakan salah satu tempat pelelangan ikan yang ada di Kendal. Alat penangkap ikan menjadi sarana pendukung penangkapan ikan yang sangat dibutuhkan untuk penangkapan ikan. TPI Tawang menjadi tempat bagi nelayan untuk memasarkan hasil tangkapan. Alat tangkap tersebut dibedakan dalam 2 kelompok metode pengoperasian, yaitu alat tangkap pasif dan aktif. Alat penangkap ikan dengan pengoperasian pasif di TPI Tawang adalah Gill net, Trammel net, dan Trap. Alat penangkap ikan dengan pengoperasian aktif di TPI Tawang adalah Mini trawl, Boat Seine, dan Purse Seine Waring Berdasarkan permasalahan tersebut, maka perlu dilakukan penelitian mengenai pengembangan perikanan tangkap berbasis CCRF. Konsep perikanan yang bertanggung jawab salah satunya adalah alat penangkap ikan yang ramah lingkungan.

Pengunaan alat tangkap ramah lingkungan yang sesuai dengan CCRF harus dilakukan sesuai dengan 9 kriteria. Kriteria alat tangkap ramah lingkungan yaitu memiliki selektifitas tinggi, tidak merusak habitat ikan, tidak membahayakan nelayan, menghasilkan ikan bermutu baik, produk tidak membahayakan konsumen, hasil tangkapan yang tebuang minimum, alat tangkap yang digunakan harus memberikan dampak minimum terhadap keanekaan sumberdaya hayati (biodiversity), tidak menangkap jenis yang dilindungi undang-undang atau yang terancam punah dan diterima secara sosial oleh masyarakat. Hal tersebut mendasari apabila tiap alat tangkap ikan perlu dilakukan kajian termasuk di TPI Tawang, dengan maksud nantinya nelayan daerah Tawang banyak menggunakan alat tangkap sesuai dengan CCRF. Keluaran yang diharapkan bahwa kegiatan overfishing dan kerusakan lingkungan pada area penangkapan dapat dicegah. Hal tersebut merupakan tujuan dari penelitian ini adalah menganalisis unit penangkapan yang sesuai dengan CCRF di TPI Tawang, Kendal.

\section{METODE PENELITIAN}

Penelitian ini dilakukan pada bulan Mei 2017, bertempat di Tempat Pelalangan Ikan (TPI) Tawang, Kendal. Informasi tentang suatu unit penangkapan ikan diperoleh dari responden yang memiliki pengetahuan cukup tentang alat tangkap. Penentuan sampel pada penelitian ini menggunakan quota sampling. Jumlah sampel yang ditentukan 96 nelayan dan terdapat 6 alat tangkap yang akan diteliti yaitu: Gill Net, Trammel Net, Arad, Payang, Purse Seine Waring dan Bubu, maka disetiap alat tangkap ditentukan sebanyak 16 nelayan karena alat tangkap Purse Seine Waring di TPI Tawang hanya terdapat 16 nelayan, untuk itu semua alat tangkap disamakan jumlah sampel untuk menghilangkan nilai bias.

Metode analisis data yang dilakukan sesuai dengan kriteria pembobotan alat tangkap ramah lingkungan yang dikeluarkan oleh Departemen Kelautan dan Perikanan tahun 2006. Pembobotan tersebut berdasarkan pada 9 kriteria alat tangkap ramah lingkungan sesuai Code of Conduct for Responsible Fisheries (CCRF) tahun 1995. Food Agriculture Organization (FAO, sebuah lembaga di bawah naungan Perserikatan Bangsa Bangsa yang menangani masalah pangan dan pertanian dunia), pada tahun 1995 mengeluarkan suatu tata cara bagi kegiatan penangkapan ikan yang bertanggung jawab (Code of Conduct for Resposible Fisheries- CCRF). Dalam CCRF ini, FAO menetapkan serangkaian kriteria bagi teknologi penangkapan ikan ramah lingkungan.

Setelah skor atau nilai sudah di dapat, kemudian di buat refrensi poin yang dapat menjadi titik acuan dalam menentukan rangking. Disini skor atau nilai maksimumnya adalah 36 point, sedangkan kategori alat tangkap ramah lingkungan akan di bagi menjadi 4 kategori dengan rentang nilai sebagai berikut: 1 - 9 sangat tidak ramah lingkungan, $10-$ 18 tidak ramah lingkungan, 19 - 27 ramah lingkungan, 28 - 36 sangat ramah lingkungan. Sehingga untuk menentukan hasil akhirnya yaitu; jumlah total bobot nilai dibagi total responden atau digunakan rumus ketatapan sebagai berikut (Aditya et al. 2013 dalam Sima et al., 2013).

$$
\begin{aligned}
& \Sigma X=\frac{\Sigma X 1-X 2 \ldots X n}{n} \\
& =\frac{\Sigma X n}{n}
\end{aligned}
$$

Keterangan :

$\mathrm{Xn}=$ jumlah total bobot nilai

$\mathrm{n}=$ total responden

\begin{tabular}{|c|c|c|c|}
\hline No & Kriteria & Penjelasan & Bobot \\
\hline \multirow[t]{4}{*}{1} & $\begin{array}{l}\text { Memiliki selektivitas yang } \\
\text { tinggi }\end{array}$ & $\begin{array}{l}\text { Alat tangkap tersebut diupayakan hanya dapat menangkap ikan/organisme lain } \\
\text { yang menjadi sasaran penangkapan saja. Ada dua macam selektivitas yang } \\
\text { menjadi sub-kriteria, yaitu selektivitas ukuran dan selektivitas jenis. Sub kriteria } \\
\text { ini terdiri dari: }\end{array}$ & \\
\hline & & - Alat menangkap lebih dari tiga spesies dengan ukuran yang berbeda jauh & 1 \\
\hline & & - Alat menangkap tiga spesies dengan ukuran yang berbeda jauh & 2 \\
\hline & & $\begin{array}{l}\text { - Alat menangkap kurang dari tiga spesies dengan ukuran yang kurang lebih } \\
\text { sama }\end{array}$ & 3 \\
\hline
\end{tabular}

Tabel 1. Pembobotan Kriteria Alat Tangkap Ramah Lingkungan

${ }^{\circ}$ Copyright by Saintek Perikanan (Indonesian Journal of Fisheries Science and Technology), ISSN : 1858-4748 
- Alat menangkap satu spesies saja dengan ukuran yang kurang lebih sama

2 Tidak merusak habitat, Kriteria yang ditetapkan berdasar luas dan tingkat kerusakan yang ditimbulkan tempat tinggal dan UPI, dengan pembobotan:

berkembang biak ikan atau - Menyebabkan kerusakan habitat pada wilayah yang luas

- Menyebabkan kerusakan habitat pada wilayah yang sempit

organisme lainnya

- Menyebabkan sebagian habitat pada wilayah yang sempit

- Aman bagi habitat (tidak merusak habitat)

3 Tidak membahayakan Keselamatan manusia menjadi syarat penangkapan ikan, karena manusia nelayan (penangkap ikan) merupakan bagian yang penting bagi keberlangsungan perikanan yang produktif. Pembobotan resiko diterapkan berdasar tingkat bahaya dan dampak yang mungkin dialami oleh nelayan, yaitu:

- Alat tangkap dan cara penggunaannya dapat berakibat kematian pada nelayan

- Alat tangkap dan penggunaannya dapat berakibat cacat permanen pada nelayan

- Alat tangkap dan penggunaannya dapat berakibat gangguan kesehatan yang sifatnya sementara

- Alat tangkap aman bagi nelayan

4 Menghasilkan ikan yang Tingkat kualitas ikan ditentukan berdasarkan kondisi hasil tangkapan secara bermutu baik morfologis (bentuknya), dengan pembobotan:

- Ikan mati dan busuk

- Ikan mati, segar dan cacat fisik

- Ikan mati segar

- Ikan hidup

Ikan yang ditangkap dengan bom, pupuk kimia atau racun sianida kemungkinan

5 Produk tidak membahayakan kesehatan konsumen tercemar racun. Pembobotan kriteria ditetapkan berdasarkan tingkat bahaya yang mungkin dialami konsumen, yaitu:

- Berpeluang besar menyebabkan kematian

- Berpeluang menyebabkan gangguan kesehatan konsumen

- Berpeluang sangat kecil bagi gangguan kesehatan konsumen

- Aman bagi konsumen

6 Hasil tangkapan yang terbuang minimum
Alat tangkap yang tidak selektif mengakibatkan hasil tangkapan yang terbuang akan meningkat, karena banyak jenis non-target yang turut tertangkap. Hasil tangkapan non-target, ada yang bisa dimanfaatkan dan ada yang tidak. Pembobotan kriteria ini ditetapkan berdasarkan pada hal berikut:

- Hasil tangkapan sampingan (by-catch) terdiri dari beberapa jenis (spesies) yang 1 tidak laku dijual di pasar

- by-catch terdiri dari beberapa jenis dan ada yang laku dijual di pasar 2

- by-catch kurang dari tiga jenis dan laku dijual di pasar 3

- by-catch kurang dari tiga jenis dan berharga tinggi di pasar

7 Alat tangkap yang digunakan Pembobotan kriteria ini ditetapkan berdasar pada hal berikut: harus memberikan dampak minimum terhadap keanekaan sumberdaya hayati (biodiversity)

- Alat tangkap dan operasinya menyebabkan kematian semua makhluk hidup dan merusak habitat

- Alat tangkap dan operasinya menyebabkan kematian beberapa spesies dan merusak habitat

- Alat tangkap dan operasinya menyebabkan kematian beberapa spesies tetapi tidak merusak habitat

- Aman bagi keanekaan sumberdaya hayati

Tingkat bahaya alat tangkap terhadap spesies yang dilindungi undang-undang ditetapkan berdasarkan kenyataan bahwa:

- Ikan yang dilindungi undang-undang sering tertangkap alat

8 Tidak menangkap jenis yang dilindungi undang-undang atau terancam punah

- Ikan yang dilindungi undang-undang beberapa kali tertangkap alat

- Ikan yang dilindungi pernah tertangkap

- Ikan yang dilindungi tidak pernah tertangkap

Penerimaan masyarakat terhadap suatu alat tangkap, akan sangat tergantung pada kondisi sosial, ekonomi, dan budaya di suatu tempat. Suatu alat diterima secara sosial oleh masyarakat bila: (1) biaya investasi murah, (2) menguntungkan secara ekonomi, (3) tidak bertentangan dengan budaya setempat, (4) tidak bertentangan dengan peraturan yang ada. Pembobotan kriteria ditetapkan dengan menilai kenyataan di lapangan bahwa:

- Alat tangkap memenuhi satu dari empat butir pernyataan di atas 
Sumber: FAO (1995).

\section{HASIL DAN PEMBAHASAN}

\section{Status alat tangkap Gill Net berdasarkan sembilan kriteria alat tangkap ramah lingkungan \\ Hasil wawancara terhadap responden alat tangkap Gill} Net di TPI Tawang diperoleh nilai presentase indikator dari sembilan kategori alat tangkap ramah lingkungan tersaji pada Tabel 2.

Tabel 2. Persentase Responden Alat Tangkap Gill Net

\begin{tabular}{lllll}
\hline \multirow{2}{*}{ Kategor } & \multicolumn{4}{l}{ Presentase indikator (\%) } \\
\cline { 2 - 5 } & I & II & III & IV \\
\hline 1 & 0 & 25 & $75^{*}$ & 0 \\
2 & 0 & 0 & 12,5 & $87,5^{*}$ \\
3 & 0 & 0 & 12,5 & $87,5^{*}$ \\
4 & 0 & 0 & 50 & 50 \\
5 & 0 & 0 & 31 & $69^{*}$ \\
6 & 0 & 0 & 37,5 & $62,5^{*}$ \\
7 & 0 & 0 & 37,5 & $62,5^{*}$ \\
8 & 0 & 0 & 0 & $100^{*}$ \\
9 & 0 & 0 & 6 & $94^{*}$ \\
\hline
\end{tabular}

Sumber: Hasil Penelitian, 2017.

Keterangan:

I : Alat penangkap ikan ramah lingkungan dengan bobot 1

II : Alat penangkap ikan ramah lingkungan dengan bobot 2

III : Alat penangkap ikan ramah lingkungan dengan bobot 3

IV : Alat penangkap ikan ramah lingkungan dengan bobot 4 *Presentase tertinggi

Gill net di TPI Tawang memiliki selektivitas tinggi, karena menangkap kurang dari tiga spesies dengan ukuran yang kurang lebih sama. Hasil tangkapan alat tangkap Jaring Rampus (Gill net) yaitu Kembung (Rastrelliger sp.), Peperek (Leiognatus equllus) dan Selar (Selaroides leptolepis). Menurut Departemen Kelautan dan Perikanan (2006), ada dua macam selektivitas yang menjadi sub kriteria, yaitu selektivitas ukuran dan selektivitas jenis. Selektivitas sangat tinggi yaitu alat menangkap satu spesies saja dengan ukuran yang kurang lebih sama, selektivitas tinggi yaitu alat menangkap kurang dari tiga spesies dengan ukuran yang kurang lebih sama, selektivitas rendah yaitu alat menangkap tiga spesies dengan ukuran yang berbeda jauh, selektivitas sangat rendah yaitu alat menangkap lebih dari tiga spesies dengan ukuran yang berbeda jauh.

Alat tangkap Gill net merupakan alat tangkap aman bagi habitat ikan dan aman bagi nelayan. Hal tersebut dikarenakan pengoperasian alat tangkap Gill net bersifat pasif menunggu ikan-ikan tertangkap karena ikan menabrak jaring dan kemudian tersangkut atau terbelit dan dioperasikan tidak jauh dari bibir pantai. Menurut Chanafi et al. (2013), Gill net merupakan alat tangkap pasif yang pada prinsipnya alat tangkap tersebut hanya menunggu ruaya ikan/udang.

Ikan hasil tangkapan Gill net tidak membahayakan konsumen dan kondisinya dalam keadaan mati segar, karena ikan yang terjerat di jaring berpeluang untuk mati dalam kondisi masih segar karena kerusakan dibagian operculum dan tutup operkulumnya. Menurut Metusalach et al. (2014), bahwa alat tangkap jaring insang secara fisik akan mengakibatkan kerusakan pada tubuh ikan hasil tangkapan hanya di bagian tutup insangnya karena jeratan dari bukaan mesh size gill net.

Hasil tangkapan sampingan (by catch) yaitu ikan Peperek (Leiognatus equllus) dan Selar (Selaroides leptolepis). Kedua hasil tangkapan tersebut laku dijual di pasar dan memiliki harga jual yang tinggi, sedangkan hasil tangkapan utama ikan Kembung (Rastrelliger sp.) memiliki harga jual Rp.14.000,-/Kg. Menurut Suadela (2004), bahwa by-catch yang dihasilkan sedikit atau para nelayan memanfaatkan hasil tangkapannya. Jika hasil tangkapan sampingan $\geq 60 \%$, banyak yang dimanfaatkan maka dapat dikatakan ramah lingkungan.

Alat tangkap Gill net merupakan alat tangkap yang pengoperasiannya pasif menghadang ikan. Dengan selektivitas yang tinggi, serta ukuran alat tangkap ikan-ikan kecil akan lolos dan tidak tertangkap sehingga tidak mengakibatkan kematian semua makhluk hidup di perairan dan tidak merusak habitat. Menurut Rusmilyansari (2012), alat tangkap gill net tergolong alat tangkap ramah lingkungan, tidak merusak habitat dan tergolong aman terhadap biodiversitas. Alat tangkap Gill net aman bagi keanekaan sumber hayati.

By catch atau incidental catch Gill net di TPI Tawang tidak ada ikan atau biota dilindungi yang ikut tertangkap seperti penyu. Dari kajian ekonomi, investasi alat Gill net sebesar Rp. 6.000.000,-, namun pengembalian investasi dari pembelian alat dapat dilakukan dalam waktu 2 bulan. Dapat disimpulkan bahwa alat tangkap Gill net menguntungkan secara ekonomis. Dari kajian konflik, Gill net tidak pernah mengalami konflik dengan alat tangkap yang lain. Disamping itu, Gill net termasuk kelompok alat tangkap sesuai dengan PERMEN No.71/PERMEN-KP/2016 pasal 29 ayat 1(b).

Gill net di TPI Tawang merupakan alat tangkap yang dikelompokkan sebagai alat tangkap sangat ramah lingkungan, karena alat tangkap ini memiliki selektivitas tinggi, aman bagi habitat, tidak membahayakan bagi nelayan, produk tidak membahayakan konsumen, by-catch minimum, berdampak minimum terhadap biodiversitas, tidak menangkap ikan yang dilindungi undang-undang dan menguntungkan secara ekonomis. Menurut Nanholy (2013), jaring insang (gill net) merupakan alat tangkap yang sangat ramah lingkungan, oleh karena itu alat tangkap ini cukup mendukung terhadap aspek ramah lingkungan. Alat ini mempunyai selektivitas yang tinggi dan tidak berpengaruh terhadap habitat.

\section{Status alat tangkap Trammel Net berdasarkan sembilan kriteria alat tangkap ramah lingkungan \\ Hasil wawancara terhadap responden alat tangkap} Trammel Net di TPI Tawang diperoleh nilai presentase indikator dari sembilan kategori alat tangkap ramah lingkungan tersaji pada Tabel 3.

Trammel net di TPI Tawang memiliki selektivitas tinggi, karena menangkap kurang dari tiga spesies dengan ukuran yang kurang lebih. Hasil tangkapan yaitu Udang putih (Penaeus merguiensis), Tigawaja (Otolithes ruber) dan Peperek (Leioghnatus equllus). Ikan yang tertangkap pada alat tangkap umumnya dengan terpuntal (entangled). Menurut Departemen Kelautan dan Perikanan (2006), ada dua macam selektivitas yang menjadi sub kriteria, yaitu selektivitas ukuran

\footnotetext{
${ }^{\circ}$ Copyright by Saintek Perikanan (Indonesian Journal of Fisheries Science and Technology), ISSN : 1858-4748
} 
dan selektivitas jenis. Selektivitas sangat tinggi yaitu alat menangkap satu spesies saja dengan ukuran yang kurang lebih sama, selektivitas tinggi yaitu alat menangkap kurang dari tiga spesies dengan ukuran yang kurang lebih sama, selektivitas rendah yaitu alat menangkap tiga spesies dengan ukuran yang berbeda jauh, selektivitas sangat rendah yaitu alat menangkap lebih dari tiga spesies dengan ukuran yang berbeda jauh.

Tabel 3. Persentase responden alat tangkap Trammel Net

\begin{tabular}{|c|c|c|c|c|}
\hline Kategori & \multicolumn{4}{|c|}{ Presentase indikator (\%) } \\
\hline & I & II & III & IV \\
\hline 1 & 0 & 44 & $56^{*}$ & 0 \\
\hline 2 & 0 & 0 & 12,5 & $87,5 *$ \\
\hline 3 & 0 & 0 & 19 & $81 *$ \\
\hline 4 & 0 & 0 & $56^{*}$ & 44 \\
\hline 5 & 0 & 0 & 19 & $81 *$ \\
\hline 6 & 0 & 13 & 31 & $56^{*}$ \\
\hline 7 & 0 & 0 & 19 & $81 *$ \\
\hline 8 & 0 & 0 & 0 & $100 *$ \\
\hline 9 & 0 & 0 & 31 & $69 *$ \\
\hline
\end{tabular}

Sumber: Hasil Penelitian, 2017.

Keterangan:

I : Alat penangkap ikan ramah lingkungan dengan bobot 1

II : Alat penangkap ikan ramah lingkungan dengan bobot 2

III : Alat penangkap ikan ramah lingkungan dengan bobot 3

IV : Alat penangkap ikan ramah lingkungan dengan bobot 4 *Presentase tertinggi

Alat tangkap Trammel net merupakan alat tangkap yang tidak merusak lingkungan, aman bagi habitat ikan dan aman bagi nelayan. Hal tersebut dikarenakan pengoperasiannya bersifat pasif. Menurut Usemahu dan Leopold (2004), trammel net dioperasikan di perairan pantai dan juga di perairan bebas. Sifat dari trammel net yang pasif ini di maksud untuk menghadang berenangnya ikan terutama jenis ikan yang hidupnya bergerombol.

Ikan hasil tangkapan Trammel net memiliki mutu yang rendah dan tidak membahayakan konsumen, karena ikan yang terpuntal dan terjerat di jaring menyebabkan ikan hasil tangkapan mengalami kerusakan pada bagian fisik ikan. Menurut Metusalach et al. (2014), bahwa alat tangkap jaring insang mengakibatkan memar dan luka dan bahkan ikan menjadi rusak secara fisik.

Hasil tangkapan sampingan (by catch) merupakan hasil tangkapan yang bukan menjadi target utama alat tangkap. Tangkapan sampingan alat tangkap Trammel net di TPI Tawang yaitu Tigawaja (Otolithes ruber) dan Peperek (Leioghnatus equllus). Kedua hasil tangkapan tersebut laku dijual di pasar dan memiliki harga jual yang tinggi, sedangkan hasil tangkapan utama Udang putih (Penaeus merguiensis) memiliki harga jual Rp.40.000,-/Kg. Menurut Suadela (2004), bahwa by-catch yang dihasilkan sedikit atau para nelayan memanfaatkan hasil tangkapannya. Jika hasil tangkapan sampingan $\geq 60 \%$, banyak yang dimanfaatkan maka dapat dikatakan ramah lingkungan.

Alat tangkap Trammel net merupakan alat tangkap yang pengoperasiannya pasif yaitu menghadang ikan. Dengan selektivitas tinggi, karena menangkap kurang dari tiga spesies dengan ukuran yang kurang lebih sama, menjadikan Trammel net aman bagi sumberdaya hayati. Selain itu, daerah pengoperasiannya tidak jauh dari pantai dengan dasar perairan dengan dasar pasir berlumpur. Hasil tangkapan Trammel net di TPI Tawang tidak ada ikan atau biota dilindungi yang ikut tertangkap seperti penyu. Menurut Keputusan Mentri Kelautan dan Perikanan No.4/Kepmen-KP/2014 tentang biota laut dan pantai yang dilindungi oleh pemerintah, salah satu penyu yang dilindungi diantaranya ialah penyu sisik (Eretmocefys turtle).

Trammel net merupakan alat tangkap yang cukup mahal dengan biaya investasi sebesar Rp. 10.000.000,-Meskipun alat tangkap trammel net tergolong mahal, namun tangkapan utama trammel net bernilai jual sangat tinggi. Jadi, dapat disimpulkan bahwa alat tangkap trammel net menguntungkan secara ekonomis, tidak pernah mengalami konflik dengan alat tangkap yang lain dan tidak ada peraturan yang melarang pengoperasian trammel net di Indonesia sehingga secara keseluruhan alat tangkap trammel net diterima secara sosial. Hal ini sesuai dengan PERMEN No.71/PERMEN-KP/2016, trammel net merupakan API yang bersifat pasif dioperasikan dengan menggunakan ukuran mesh size $>1$ inch, $\mathrm{P}<1.000 \mathrm{~m}$, menggunakan kapal tanpa motor dan kapal motor berukuran $<30$ GT, dan dioperasikan pada Jalur Penangkapan Ikan IA, Jalur Penangkapan Ikan IB, dan Jalur Penangkapan Ikan II di semua WPPNRI

Alat tangkap Trammel net di TPI Tawang merupakan alat tangkap yang sangat ramah lingkungan, karena alat tangkap ini memiliki selektivitas tinggi, aman bagi habitat, tidak membahayakan bagi nelayan, produk tidak membahayakan konsumen, by-catch minimum, berdampak minimum terhadap biodiversitas, tidak menangkap ikan yang dilindungi undang-undang dan menguntungkan secara ekonomis. Kelebihan dari alat tangkap Trammel net ini adalah hasil tangkapan Udang putih (Penaeus merguiensis) yang bernilai harga jual tinggi.

\section{Status alat tangkap Mini trawl berdasarkan sembilan kriteria alat tangkap ramah lingkungan}

Hasil wawancara terhadap responden alat tangkap Mini trawl di TPI Tawang diperoleh nilai presentase indikator dari sembilan kategori alat tangkap ramah lingkungan tersaji pada Tabel 4.

abel 4. Persentase responden alat tangkap Mini trawl

\begin{tabular}{lllll}
\hline Kategori & \multicolumn{4}{c}{ Presentase indikator (\%) } \\
\cline { 1 - 4 } & I & \multicolumn{1}{c}{ II } & III & IV \\
\hline 1 & $100^{*}$ & 0 & 0 & 0 \\
2 & $100^{*}$ & 0 & 0 & 0 \\
3 & 31 & $69 *$ & 0 & 0 \\
4 & 6 & $75^{*}$ & 19 & 0 \\
5 & 0 & $75^{*}$ & 25 & 0 \\
6 & $50^{*}$ & 44 & 6 & 0 \\
7 & $56^{*}$ & 44 & 0 & 0 \\
8 & 0 & $56^{*}$ & 38 & 6 \\
9 & 38 & $44^{*}$ & 19 & 0 \\
\hline
\end{tabular}

Sumber: Hasil Penelitian, 2017.

Keterangan:

I : Alat penangkap ikan ramah lingkungan dengan bobot 1

II : Alat penangkap ikan ramah lingkungan dengan bobot 2

III : Alat penangkap ikan ramah lingkungan dengan bobot 3

IV : Alat penangkap ikan ramah lingkungan dengan bobot 4 *Presentase tertinggi

Alat tangkap mini trawl di TPI Tawang termasuk alat tangkap yang selektivitasnya sangat rendah, karena menangkap lebih dari tiga spesies dengan ukuran yang berbeda jauh. Hasil tangkapan arad di TPI Tawang antara lain: Cumi-cumi (Loligo sp.), Peperek (Leiognatus equllus), Layur (Trichiurus lepturus), 
Kembung (Rastrelliger sp.), dengan hasil tangkapan utama Cumi-cumi (Loligo sp.). Menurut Departemen Kelautan dan Perikanan (2006), ada dua macam selektivitas yang menjadi sub kriteria, yaitu selektivitas ukuran dan selektivitas jenis. Selektivitas sangat tinggi yaitu alat menangkap satu spesies saja dengan ukuran yang kurang lebih sama, selektivitas tinggi yaitu alat menangkap kurang dari tiga spesies dengan ukuran yang kurang lebih sama, selektivitas rendah yaitu alat menangkap tiga spesies dengan ukuran yang berbeda jauh, selektivitas sangat rendah yaitu alat menangkap lebih dari tiga spesies dengan ukuran yang berbeda jauh.

Alat tangkap mini trawl merupakan alat tangkap yang menyebabkan kerusakan habitat pada wilayah yang luas dan membahayakan bagi nelayan. Hal ini disebabkan cara pengoperasian mini trawl yaitu dengan menurunkan kantong dan badan jaring, sayap, otter board, tali selambar dan ditarik secara aktif di dasar perairan dengan kapal sehingga alat tangkap arad dapat merusak habitat dan terumbu karang di dasar perairan pada wilayah yang luas dan mengancam keberlangsungan habitat. Menurut FAO (1995) dalam Hufiadi dan Maheswara (2009), jaring arad dioperasikan dengan cara ditarik menyapu dasar perairan sehingga berbagai ikan dan biota lainnya ikut tertangkap. Alat tangkap trawl dan sejenisnya dioperasikan dengan cara ditarik dengan kecepatan dan waktu tertentu di sepanjang dasar perairan untuk menangkap ikan-ikan dasar.

Hasil tangkapan mini trawl mati segar dan aman dikonsumsi, namun ada hasil tangkapan yang cacat fisik karena pada saat pengoperasian ikan yang tertangkap berkumpul di kantong dan ditarik menggunakan kapal, ikan yang ditangkap banyak dan saling berhimpitan. Menurut Metusalach (2014), operasi penangkapan dapat menangkap berbagai jenis ikan dalam jumlah banyak yang memungkinkan ikan bertumpuk/saling berhimpitan mengakibatkan memar dan luka dan bahkan ikan menjadi rusak secara fisik.

Alat tangkap mini trawl merupakan alat tangkap yang menyapu dasar perairan sehingga hasil tangkapan yang ditargetkan maupun non-target akan ikut tertangkap. Semua hasil tangkapan alat tangkap arad laku dijual di pasaran antara lain:Cumi-cumi (Loligo sp.), Peperek (Leiognatus equllus), Layur (Trichiurus lepturus), Kembung (Rastrelliger sp.) yang memiliki harga jual tinggi, terdapat pula ikan-ikan yang jenisnya tidak menentu dijual dengan sebutan ikan curah yang dijual dengan harga Rp.2000,-/Kg. Menurut FAO (1995) dalam Hufiadi dan Maheswara (2009), Jaring trawl termasuk jaring arad dikenal sebagai alat tangkap yang menghasilkan hasil tangkapan sampingan lebih banyak dibandingkan alat tangkap lainnya. Hal ini dikarenakan mini trawl atau jaring arad menggunakan mata jaring bagian kantong (cod end) relatif kecil.

Alat tangkap yang mempunyai tingkat selektivitas sangat rendah menyebabkan hasil tangkapan terbuang akan meningkat, karena banyaknya ikan non-target yang ikut tertangkap. Cara pengoperasian alat tangkap mini trawl yang menyapu dasar perairan menyebabkan kematian beberapa spesies, merusak habitat dan beberapa kali menangkap ikan yang dilindungi undang-undang. Ikan curah adalah salah satu contoh beberapa spesies ikan yang mati karena alat tangkap tersebut. Hal inilah yang menjadikan alat tangkap mini trawl berpengaruh terhadap kelangsungan sumberdaya ikan. Menurut Pascoe (1997) dalam Hufiadi dan Maheswara (2009), dalam pengoperasian jaring arad tertangkap pula berbagai jenis ikan dan organisme dasar. Juvenile dan trash fish seperti ubur-ubur, bintang laut dan kekerangan yang ikut tertangkap trawl dan sejenisnya dibuang kembali ke laut dalam keadaan mati dan diistilahkan sebagai discards (buangan) dan buangan dapat berdampak buruk terhadap sumberdaya dan lingkungan.

Alat tangkap mini trawl merupakan alat tangkap dengan biaya investasi murah. Nelayan di TPI Tawang membeli alat tangkap mini trawl dengan harga Rp.2.000.000,dan juga dapat dioperasikan setiap hari sehingga menguntungkan secara ekonomi namun dilarang oleh pemerintah maupun budaya setempat.

Alat tangkap mini trawl merupakan alat tangkap yang tidak ramah lingkungan. Alat tangkap mini trawl menangkap lebih dari tiga spesies dengan ukuran yang berbeda jauh, menyebabkan kerusakan habitat pada wilayah yang luas, penggunaannya dapat menyebabkan gangguan kesehatan bagi nelayan yang bersifat sementara, permanen maupun berakibatkan kematian, ikan yang dihasilkan mati segar dan cacat fisik, produk ikan berpeluang menyebabkan gangguan kesehatan konsumen, by-catch terdiri dari beberapa jenis dan ada yang laku dijual dipasar, alat tangkap dan operasinya menyebabkan kematian semua makhluk hidup dan merusak habitat, ikan yang dilindungi undang-undang beberapa kali tertangkap dan alat tangkap menguntungkan secara ekonomi namun dilarang oleh pemerintah maupun budaya setempat. Alat tangkap mini trawl di TPI Tawang seharusnya tidak diperbolehkan untuk beroperasi. Hal ini sesuai dengan PERMEN No.71/PERMEN-KP/2016, API pukat hela dasar (bottom trawls), pukat hela pertengahan (midwater trawls), dan pukat hela kembar berpapan (otter twin trawls) merupakan API yang bersifat aktif dan dilarang beroperasi di semua Jalur Penangkapan Ikan dan di semua WPPNRI.

\section{Status alat tangkap Boat Seine berdasarkan sembilan kriteria alat tangkap ramah lingkungan}

Hasil wawancara terhadap responden alat tangkap Boat Seine di TPI Tawang diperoleh nilai presentase indikator dari sembilan kategori alat tangkap ramah lingkungan tersaji pada Tabel 5.

Tabel 5. Persentase responden alat tangkap Boat Seine

\begin{tabular}{lllll}
\cline { 1 - 3 } Kategori & \multicolumn{4}{c}{ Presentase indikator (\%) } \\
\cline { 1 - 2 } & I & \multicolumn{1}{c}{ II } & \multicolumn{1}{c}{ III } & IV \\
\hline 1 & $81^{*}$ & 19 & 0 & 0 \\
2 & 0 & 38 & $44^{*}$ & 19 \\
3 & 0 & 0 & $56^{*}$ & 44 \\
4 & 0 & 12,5 & $62,5^{*}$ & 25 \\
5 & 0 & 0 & $69^{*}$ & 31 \\
6 & 0 & $87,5^{*}$ & 12,5 & 0 \\
7 & 0 & 0 & $62,5 *$ & 37,5 \\
8 & 0 & 0 & $81^{*}$ & 19 \\
9 & 0 & 44 & $56^{*}$ & 0 \\
\hline
\end{tabular}

Sumber: Hasil Penelitian, 2017.

Keterangan:

I : Alat penangkap ikan ramah lingkungan dengan bobot 1

II : Alat penangkap ikan ramah lingkungan dengan bobot 2

III : Alat penangkap ikan ramah lingkungan dengan bobot 3

IV : Alat penangkap ikan ramah lingkungan dengan bobot 4 *Presentase tertinggi

Alat tangkap boat seine merupakan alat tangkap yang selektivitasnya sangat rendah karena menangkap lebih dari tiga

${ }^{\circ}$ Copyright by Saintek Perikanan (Indonesian Journal of Fisheries Science and Technology), ISSN : 1858-4748 
spesies dengan ukuran yang berbeda jauh. Hasil tangkapan alat tangkap payang antara lain: Ikan Teri (Stolephorus sp.), Japuh (Dussumeiria sp.), Peperek (Leiognatus equllus) dan Selar (Selaroides leptolepis). Ketidakselektif alat tangkap payang dikarenakan alat tangkap tersebut pada bagian kantong menggunakan bahan waring yang ukuran mata jaringnya kecil sehingga ikan bermacam jenis dan ukuran ikut tertangkap. Menurut Departemen Kelautan dan Perikanan (2006), ada dua macam selektivitas yang menjadi sub kriteria, yaitu selektivitas ukuran dan selektivitas jenis. Selektivitas sangat tinggi yaitu alat menangkap satu spesies saja dengan ukuran yang kurang lebih sama, selektivitas tinggi yaitu alat menangkap kurang dari tiga spesies dengan ukuran yang kurang lebih sama, selektivitas rendah yaitu alat menangkap tiga spesies dengan ukuran yang berbeda jauh, selektivitas sangat rendah yaitu alat menangkap lebih dari tiga spesies dengan ukuran yang berbeda jauh.

Alat tangkap boat seine tidak menyebabkan kerusakan pada wilayah yang luas dan dapat berakibat gangguhan kesehatan yang sifatnya bagi nelayan, karena alat tangkap payang dioperasikan di permukaan perairan sehingga tidak merusak dasar perairan atau terumbu karang. Namun pada dasarnya alat tangkap yang dioperasikan secara aktif akan menyapu lingkaran yang ada dijaring sehingga menyebabkan kerusakan pada sebagian habitat pada wilayah yang sempit. Menurut Hakim et al. (2014), alat tangkap Payang adalah pukat kantong yang digunakan untuk menangkap gerombolan ikan permukaan (pelagic fish) dimana kedua sayapnya berguna untuk menakut-nakuti atau mengejutkan serta menggiring ikan supaya masuk ke dalam kantong.

Ikan yang dihasilkan pada alat tangkap boat seine masih segar, karena ikan yang ditangkap langsung dilakukan hauling setelah itu dimasukkan di blong yang sudah diberi es. Namun, terdapat hasil tangkapan yang cacat fisik karena pada saat pengoperasian ikan yang tertangkap berkumpul di kantong dan ditarik, ikan yang ditangkap banyak dan saling berhimpitan. Hasil tangkapan utama boat seine adalah Ikan Teri (Stolephorus sp.), sedangkan hasil tangkapan sampingan alat tangkap payang adalah Japuh (Dussumeiria sp.), Peperek (Leiognatus equllus) dan Selar (Selaroides leptolepis). Menurut Metusalach (2014), operasi penangkapan dapat menangkap berbagai jenis ikan dalam jumlah banyak yang memungkinkan ikan bertumpuk/saling berhimpitan mengakibatkan memar dan luka dan bahkan ikan menjadi rusak secara fisik. Menururt Bintang et al. (2015), alat tangkap yang dikatakan ramah lingkungan yaitu apabila hasil tangkapan sampingannya minimum dan memprioritaskan hasil tangkap utama.

Dampak terhadap lingkungan Alat tangkap boat seine di TPI Tawang tidak berdampak langsung terhadap keanekaragaman (biodiversity) karena alat tangkap tersebut di operasikan di permukaan perairan dan tidak menggunakan mesin bantu penangkapan, namun dikarenakan kantong alat tangkapan boat seine bahan dari waring dan melingkari gerombolan ikan secara aktif, maka menyebabkan kematian dari beberapa spesies tetapi tidak merusak habitat. Dan menyebabkan ikan yang dilindungi pernah tertangkap seperti penyu.

Biaya untuk membeli alat tangkap boat seine sebesar Rp.15.000.000,- sehingga biaya investasi untuk alat tangkap payang mahal. Namun, karena hasil tangkapan utama payang yaitu ikan Teri (Stolephorus sp.) harga di TPI Tawang tergolong murah karena banyaknya stock ikan Teri
(Stolephorus sp.) di Kendal. Alat tangkap payang diterima dimasyarakat. Alat tangkap payang di TPI Tawang termasuk alat tangkap payang teri, sehingga diperbolehkan oleh pemerintah tetapi diatur penggunaannya. Hal ini sesuai dengan PERMEN No.71/PERMEN-KP/2016, API payang merupakan API yang bersifat aktif tanpa menggunakan mesin bantu penangkapan (fishing machinery) dan dioperasikan dengan menggunakan ukuran mesh size $\geq 1$ inch dan tali ris atas $\leq 100$ $\mathrm{m}$ (kecuali mesh size payang teri $\geq 1 \mathrm{~mm}$ ), menggunakan kapal motor berukuran $>5$ s.d. $10 \mathrm{GT}$, dan dioperasikan pada Jalur Penangkapan Ikan IB, Jalur Penangkapan Ikan II, dan Jalur Penangkapan Ikan III di semua WPPNRI.

Alat tangkap payang di TPI Tawang merupakan alat tangkap yang ramah lingkungan. Alat tangkap payang memenuhi beberapa kriteria antara lain: menguntungkan secara ekonomis dan diperbolehkan pemerintah mmaupun masyarakat, namun nelayan mengeluhkan biaya investasi terlalu mahal, produk ikan yang dihasilkan mati segar, berpeluang sangat kecil bagi gangguan kesehatan konsumen, alat tangkap tidak membahayakan nelayan, kerusakan habitat pada wilayah yang sempit dan menyebabkan kematian beberapa spesies tetapi tidak merusak habitat. Sedangkan kriteria yang tidak terpenuhi adalah alat menangkap lebih dati tiga spesies dengan ukuran yang berbeda jauh dan ikan yang dilindungi pernah tertangkap.

\section{Status alat tangkap Purse seine Waring berdasarkan sembilan kriteria alat tangkap ramah lingkungan}

Hasil wawancara terhadap responden alat tangkap Purse seine Waring di TPI Tawang diperoleh nilai presentase indikator dari sembilan kategori alat tangkap ramah lingkungan tersaji pada Tabel 6 .

Tabel 6. Persentase responden alat tangkap Purse seine Waring

\begin{tabular}{lllll}
\hline Kategori & \multicolumn{4}{c}{ Presentase indikator (\%) } \\
\hline & I & \multicolumn{1}{c}{ II } & III & \multicolumn{1}{c}{ IV } \\
\hline 1 & $75^{*}$ & 25 & 0 & 0 \\
2 & $62,5^{*}$ & 37,5 & 0 & 0 \\
3 & 0 & 0 & $62,5^{*}$ & 37,5 \\
4 & 0 & 0 & $56^{*}$ & 44 \\
5 & 0 & 0 & 0 & $100^{*}$ \\
6 & 0 & $87,5^{*}$ & 12,5 & 0 \\
7 & 0 & $62,5^{*}$ & 37,5 & 0 \\
8 & 31 & $69^{*}$ & 0 & 0 \\
9 & 0 & 0 & $69 *$ & 31 \\
\hline
\end{tabular}

Keterangan:

Sumber: Hasil Penelitian, 2017.

I : Alat penangkap ikan ramah lingkungan dengan bobot 1

II : Alat penangkap ikan ramah lingkungan dengan bobot 2

III : Alat penangkap ikan ramah lingkungan dengan bobot 3

IV : Alat penangkap ikan ramah lingkungan dengan bobot 4 *Presentase tertinggi

Alat tangkap Purse seine Waring merupakan alat tangkap yang selektivitasnya rendah karena menangkap tiga spesies dengan ukuran yang berbeda jauh. Hasil tangkapan alat tangkap Purse seine Waring antara lain: Ikan Teri (Stolephorus sp.), Japuh (Dussumeiria sp.) dan Selar (Selaroides leptolepis). Ketidakselektif alat tangkap Purse seine Waring dikarenakan badan jaring alat tangkap tersebut bahan waring sehingga ikan berbagai macam ukuran ikut tertangkap. Menurut Departemen Kelautan dan Perikanan (2006), ada dua macam selektivitas yang menjadi sub kriteria, 
yaitu selektivitas ukuran dan selektivitas jenis. Selektivitas sangat tinggi yaitu alat menangkap satu spesies saja dengan ukuran yang kurang lebih sama, selektivitas tinggi yaitu alat menangkap kurang dari tiga spesies dengan ukuran yang kurang lebih sama, selektivitas rendah yaitu alat menangkap tiga spesies dengan ukuran yang berbeda jauh, selektivitas sangat rendah yaitu alat menangkap lebih dari tiga spesies dengan ukuran yang berbeda jauh. Pada penelitian ini, dominansi hasil tangkapan adalah ikan Teri, karena operasi penangkapan saat penelitian dilakukan saat musim puncak ikan Teri (bulan Maret dan April). Sebagaimana dijelaskan Setyasmoko (2015), bahwa musim Teri di perairan Utara Jawa Tengah berkisar pada bulan Februari sampai dengan bulan Mei.

Alat tangkap Purse seine Waring menyebabkan kerusakan habitat pada wilayah yang luas namun tergolong aman bagi nelayan, karena lingkar pada alat tangkap Purse seine Waring $300 \mathrm{~m}$. Pengoperasian alat tangkap Purse seine Waring melingkarkan jaring dan kemudian tali kolor ditarik dan dilakukan hauling, sehingga ikan yang sudah terlingkar oleh alat tangkap akan ikut terambil semua karena badan jaring berbahan waring. Dalam melaut alat tangkap Purse seine Waring dilakukan sebanyak tiga kali pengoperasian. Menurut Setyasmoko (2015), Purse seine waring merupakan alat tangkap yang dalam operasi penangkapan dengan pelingkaran jaring pada fish target lalu bagian bawah jaring dikerucutkan dengan menarik purse line. Ikan yang tertangkap di dalam jaring tidak dapat meloloskan diri. Fungsi dari badan jaring bukan sebagai penjerat, melainkan sebagai dinding yang akan menghalangi ikan untuk lolos.

Ikan yang dihasilkan pada alat tangkap Purse seine Waring masih segar, karena pada saat hauling iakan hasil tangkapan langsung dimasukkan di blong yang sudah diberi es. Hasil tangkapan langsung dibedakan spesiesnya yang langsung dimasukkan ke blong yang sudah disiapkan. Ikan yang dimasukkan di blong memungkinkan ikan akan mati tetapi dalam keadaan segar. Hasil tangkapan Purse Seine Waring yang dalam jumlah banyak mengakibatkan ikan berhimpitan pada saat dilakukannya hauling. Ikan hasil tangkapan Purse seine Waring tidak membahayakan konsumen. Menurut Metusalach (2014), operasi penangkapan dapat menangkap berbagai jenis ikan dalam jumlah banyak yang memungkinkan ikan bertumpuk/saling berhimpitan mengakibatkan memar dan luka dan bahkan ikan menjadi rusak secara fisik.

Hasil tangkapan utama Purse seine Waring adalah Ikan Teri (Stolephorus sp.) dengan harga Rp.20.000,-/Kg., sedangkan hasil tangkapan sampingan alat tangkap Purse seine Waring adalah Japuh (Dussumeiria sp.) dengan harga Rp.5.000,-/Kg dan Selar (Selaroides leptolepis) dengan harga Rp.4.000,-/Kg. Menurut Suadela (2004), bahwa by-catch yang dihasilkan sedikit atau para nelayan memanfaatkan hasil tangkapannya. Jika hasil tangkapan sampingan $\geq 60 \%$, banyak yang dimanfaatkan maka dapat dikatakan ramah lingkungan.

Alat tangkap Purse seine Waring operasinya menyebabkan kematian beberapa spesies dan merusak habitat, karena alat tangkap Purse seine Waring memiliki lingkar jaring $300 \mathrm{~m}$ dan tingginya $30 \mathrm{~m}$, sehingga alat tangkap Purse seine Waring menyentuh hingga dasar perairan dan karena badan jaringnya waring tidak dapat meloloskan ikan-ikan kecil dan menyebabkan ikan yang dilindungi pernah tertangkap. Menurut Setyasmoko (2015), pukat cincin (purse seine) memiliki kedalaman yang melebihi dasar perairan dapat mengancam kelestarian sumberdaya ikan yang tertangkap bukan hanya ikan pelagis saja, tetapi juga ikan demersal. Menurut Keputusan Mentri Kelautan dan Perikanan No.4/Kepmen-KP/2014 tentang biota laut dan pantai yang dilindungi oleh pemerintah, salah satu penyu yang dilindungi diantaranya ialah penyu sisik (Eretmocefys turtle).

Membeli alat tangkap Purse seine Waring seharga Rp.210.000.000,- sehingga biaya investasi alat tangkap Purse seine Waring sangat mahal. Namun, dengan alat tangkap tersebut menguntungkan secara ekonomi karena dengan besarnya alat tangkap akan mendapatkan hasil tangkapan yang banyak. Alat tangkap Purse seine Waring tidak bertentangaan dengan budaya setempat dan untuk alat tangkap Purse seine di dalam pemerintah diperbolehkan, namun untuk Purse seine Waring perlu dilakukan pengkajian peraturannya.

Alat tangkap Purse seine Waring merupakan alat tangkap yang ramah lingkungan, karena memenuhi beberapa kriteria antara lain: menguntungkan secara ekonomi dan tidak bertentangan dengan budaya setempat dan produk yang dihasilkan bermutu baik dan aman bagi konsumen. Kriteria yang belum memenuhi antara lain: alat tangkap menangkap lebih dari tiga spesies dengan ukuran yang berbeda jauh, alat tangkap dan operasinya menyebabkan kematian beberapa spesies dan merusak habitat dan ikan yang dilindungi undangundang beberapa kali ikut tertangkap.

\section{Status alat tangkap Trap berdasarkan sembilan kriteria alat tangkap ramah lingkungan}

Hasil wawancara terhadap responden alat tangkap Trap di TPI Tawang diperoleh nilai presentase indikator dari sembilan kategori alat tangkap ramah lingkungan tersaji pada Tabel 7.

Tabel 7. Persentase responden alat tangkap Trap

\begin{tabular}{lllll}
\hline Kategori & \multicolumn{4}{c}{ Presentase indikator (\%) } \\
\hline & I & II & III & IV \\
\hline 1 & 0 & 0 & $69^{*}$ & 31 \\
2 & 0 & 0 & 0 & $100^{*}$ \\
3 & 0 & 0 & 0 & $100^{*}$ \\
4 & 0 & 0 & 50 & 50 \\
5 & 0 & 0 & 0 & $100^{*}$ \\
6 & 0 & 0 & $69 *$ & 31 \\
7 & 0 & 0 & 0 & $100^{*}$ \\
8 & 0 & 0 & 0 & $100^{*}$ \\
9 & 0 & 0 & 0 & $100^{*}$ \\
\hline
\end{tabular}

Keterangan:

Sumber: Hasil Penelitian, 2017.

I : Alat penangkap ikan ramah lingkungan dengan bobot 1

II : Alat penangkap ikan ramah lingkungan dengan bobot 2

III : Alat penangkap ikan ramah lingkungan dengan bobot 3

IV : Alat penangkap ikan ramah lingkungan dengan bobot 4 *Presentase tertinggi

Trap merupakan alat tangkap yang memiliki selektivitas tinggi, yaitu menangkap kurang dari 3 spesies dengan ukuran yang kurang lebih sama. Trap di TPI Tawang menangkap rajungan (Portunus pelagicus) dengan hasil sampingan berupa kepiting (Scylla serrata). Menurut Departemen Kelautan dan Perikanan (2006), ada dua macam selektivitas yang menjadi sub kriteria, yaitu selektivitas ukuran dan selektivitas jenis. Selektivitas sangat tinggi yaitu alat menangkap satu spesies saja dengan ukuran yang kurang lebih

\footnotetext{
${ }^{\mathcal{C}}$ Copyright by Saintek Perikanan (Indonesian Journal of Fisheries Science and Technology), ISSN : 1858-4748
} 
sama, selektivitas tinggi yaitu alat menangkap kurang dari tiga spesies dengan ukuran yang kurang lebih sama, selektivitas rendah yaitu alat menangkap tiga spesies dengan ukuran yang berbeda jauh, selektivitas sangat rendah yaitu alat menangkap lebih dari tiga spesies dengan ukuran yang berbeda jauh.

Trap merupakan salah satu alat tangkap yang tidak merusak habitat maupun tempat tinggal organisme akuatik dan aman bagi nelayan. Dilihat dari pengoperasiannya, bubu merupakan alat tangkap pasif yang dioperasikan didasar perairan. Selain itu, pengoperasian bubu dilakukan pada perairan dengan substrat dasar berupa pasir berlumpur. Hal itu dapat dilihat dari target tangkapan yaitu rajungan (Portunus pelagicus) yang biasa hidup didaerah dengan substrat dasar berupa pasir berlumpur. Menurut Kordi (2010), habitat rajungan adalah pada pantai bersubstrat pasir, pasir berlumpur dan di pulau berkarang. Substrat dasar habitat sangat beragam mulai dari pasir kasar, pasir halus, pasir bercampur lumpur, sampai perairan yang ditumbuhi lamun. Rajungan (Portunus pelagicus) cenderung hidup di dasar perairan dengan bersembunyi.

Hasil tangkapan trap merupakan ikan dengan mutu yang tinggi dan aman dikonsumsi. Hal ini dikarenakan ikan hasil tangkapan yaitu rajungan (Portunus pelagicus) dan kepiting (Scylla serrata) yang masih dalam keadaan hidup. Selain itu, prinsip pengoperasian bubu yang menjebak menjadikan ikan yang ada didalamnya kecil kemungkinan untuk mengalami cacat fisik. Menurut Khikmawati et al. (2015), hasil tangkapan alat tangkap Bubu masih hidup dan segar. Memiliki bagian tubuh yang lengkap sehingga memiliki nilai jual tinggi.

Trap merupakan alat tangkap yang memiliki selektivitas tinggi dengan target tangkapan yaitu rajungan (Portunus pelagicus). Dengan selektivitas yang tinggi, menjadikan by-catch trap sedikit dan aman bagi keanekaragaman hayati, karena hasil tangkapan sampingan alat tangkap trap adalah kepiting (Scylla serrata) yang berharga tinggi dengan harga Rp.50.000,-/Kg, sedangkan hasil tangkapan utama adalah rajungan (Portunus pelagicus) dengan harga Rp.65.000,-/Kg. Menurut Gardenia (2006), hasil tangkapan utama bubu lipat ini adalah rajungan, rajungan yang tertangkap dengan jenis Portunus pelagicus. Sementara hasil tangkapan sampingan dari bubu lipat adalah rangah (Murex $s p$ ), keong macan (Babylonia spirata), udang ronggeng (Oratosquilla $s p$ ), kepiting (Scylla serata), dan cumi-cumi (Loligo sp).

Alat tangkap trap tidak pernah menangkap ikan yang dilindungi, karena mulut pada trap ditujukan untuk menangkap target utama tangkapan rajungan (Portunus pelagicus) yang berbentuk pipih lateral. Hasil tangkapan yang dapat ikut tertangkap hanyalah kepiting (Scylla serrata) saja, sehingga ikan yang dilindungi seperti penyu tidak mungkin ikut tertangkap. Menurut Bahri (2015), Bubu dalam bahasa setempat disebutnya rakkang, merupakan salah satu alat tangkap yang digunakan nelayan untuk menangkap kepiting. Bubu dirancang sebagai sebuah perangkap.

Biaya untuk membeli trap seharga Rp.25.000,-- trap, sehingga biaya investasi untuk membeli alat tangkap trap murah. Alat tangkap trap menguntungkan secara ekonomi, karena target tangkapan adalah rajungan (Portunus pelagicus) dengan nilai harga jual tinggi yaitu seharga Rp.65.000,-/Kg. Tidak ada konflik antar nelayan dalam mengoperasikan bubu dan juga tidak bertentangan dengan peraturan pemerintah.
Menurut Iskandar (2013), Bubu lipat bisa dilipat sehingga mudah untuk dibawa di kapal dengan jumlah yang banyak dan harga relative murah dibanding jenis alat tangkap lainnya.

Alat tangkap trap merupakan alat tangkap yang sangat ramah lingkungan, karena alat tangkap trap ini memenuhi kriteria antara lain: alat tangkap menangkap kurang dari tiga spesies dengan ukuran yang kurang lebih sama, alat tangkap aman bagi habitat, aman bagi keanekaan sumberdaya hayati, alat tangkap aman bagi nelayan, produk ikan hasil tangkapan masih hidup sehingga aman bagi konsumen, by-catch kurang dari tiga jenis dan laku dijual di pasar, ikan yang dilindungi tidak pernah tertangkap, alat tangkap murah, menguntungkan secara ekonomis, tidak bertentangan dengan budaya setempat dan pemerintah. Hal ini sesuai dengan PERMEN No.71/PERMEN-KP/2016, API bubu (pots) merupakan API yang bersifat pasif dioperasikan dengan jumlah bubu $\leq 300$ buah, menggunakan kapal tanpa motor dan kapal motor semua ukuran, dan dioperasikan pada Jalur Penangkapan Ikan IA, Jalur Penangkapan Ikan IB, dan Jalur Penangkapan Ikan II di semua WPPNRI.

\section{Analisis Alat Tangkap di TPI Tawang Berdasarkan Sembilan Kriteria Alat Tangkap Ramah Lingkungan}

Rentang nilai 4 kategori sebagai berikut: 1 - 9 sangat tidak ramah lingkungan, 10 - 18 tidak ramah lingkungan, 19 27 ramah lingkungan, 28 - 36 sangat ramah lingkungan. Sehingga untuk menentukan hasil akhirnya yaitu; jumlah total bobot nilai dibagi total responden. Hasil keramah lingkungan alat tangkap dapat dilihat pada Gambar 1 .

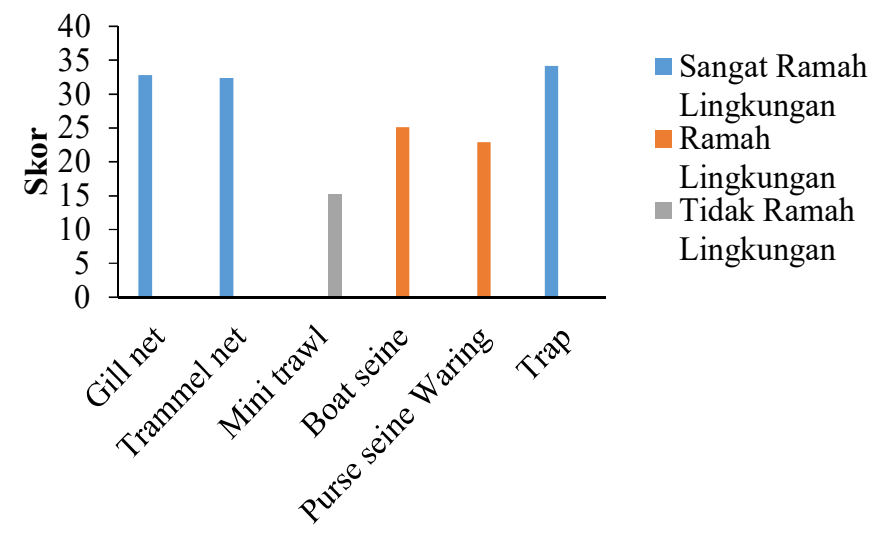

Jenis Alat Tangkap

Gambar 1. Skor Keramah Lingkungan Alat Tangkap di TPI Tawang

Berdasarkan Gambar 1. dapat diketahui nilai skorsing kriteria alat tangkap ramah lingkungan di TPI Tawang, Kendal yaitu kriteria alat tangkap sangat ramah lingkungan meliputi alat tangkap Gill net, Trammel net dan Trap dengan masingmasing skor bernilai 32,8; 32,4 dan 34,1. Kriteria alat tangkap ramah lingkungan meliputi alat tangkap Boat seine dan Purse seine Waring dengan masing-masing skor bernilai 25,1 dan 22,9 . Kriteria alat tangkap tidak ramah lingkungan meliputi alat tangkap Mini trawl dengan skor bernilai 15,3.

\section{KESIMPULAN}

Kesimpulan yang dapat di ambil pada penelitian Analisis Alat Penangkap Ikan berbasis CCRF di TPI Tawang Kendal adalah alat tangkap Gill net, Trammel net dan Trap

${ }^{\circ}$ Copyright by Saintek Perikanan (Indonesian Journal of Fisheries Science and Technology), ISSN : 1858-4748 
dengan masing-masing skor bernilai 32,8; 32,4 dan 34,1 yang merupakan alat tangkap yang sangat ramah lingkungan, alat tangkap tangkap Boat seine dan Purse seine Waring dengan masing-masing skor bernilai 25,1 dan 22,9 yang merupakan alat tangkap ramah lingkungan, sedangkan alat tangkap Mini trawl dengan skor bernilai 15,3 merupakan alat tangkap yang tidak ramah lingkungan.

\section{UCAPAN TERIMA KASIH}

Dalam kesempatan ini penulis mengucapkan terimakasih kepada Ketua Himpunan Nelayan Seluruh Indonesia Kabupaten Kendal (Bapak Ngaslan) yang telah membantu dalam pengambilan data penelitian.

\section{DAFTAR PUSTAKA}

Badan Pusat Statistik. 2013. Statistik Provinsi Jawa Tengah.

Bahri, Syamsul. 2015. Bubu dan Pukat: Teknologi Alat Tangkap Kepiting Laut oleh Masyarakat Nelayan di Pajukukang, Kabupaten Maros, Provinsi Sulawesi Selatan. Walasuji, 6(2):425-438.

Chanafi, M. Khanif Makhshun, Asriyanto, Aristi Dian Purnama Fitri. 2013. Analisis Perbandingan Letak Umpan Buatan pada Bottom set Gill net Terhadap Rajungan di Perairan Jepara, Jawa Tengah. Journal of Fisheries Resources Utilization Management and Technology. 2(4): 20-29.

Departemen Kelautan dan Perikanan. 2006. Panduan Jenis-jenis Penangkap Ikan Ramah Lingkungan. Jakarta: Bina Marina Nusantara.

Food and Agriculture Organozation. (FAO). 1995. Code of Conduct forr Responsible Fisheries. Rome.

Gardenia, Y.T. 2006. Teknologi Penangkapan Pilihan Untuk Perikanan Rajungan di Perairan Gebang Mekar Kabupaten Cirebon. Sekolah Pasca Sarjana. Institut Pertanian Bogor. Bogor.

Hakim, Lukman Guam, Asriyanto, Aristi Dian Purnama Fitri. 2014. Analisis Selektivitas Payang Ampera (Seine net) Modifikasi dengan Window Permukaan Terhadap Hasil Tangkapan Ikan Daun Bambu (Chorinemus sp.) di Perairan Kabupaten Kendal. Journal of Fisheries Resources Utilization Management and Technology. 3(2): 54-61.

Hufiadi dan Mahiswara. 2009. Selektivitas Jaring Arad (Mini Bottom Trawl) yang Dilengkapi JTEDs terhadap Ikan Beloso (Saurida sp.). 2(6): 315322.

Iskandar, Dahri. 2013. Daya Tangkap Bubu Lipat yang Dioperasikan oleh Nelayan Tradisional di Desa Mayangan, Kabupaten Subang. Jurnal Saintek Perikanan, 8(2):1-5.

Khikmawati, Liya Tri, Herry Boesono, Sardiyatmo. 2015. Pengaruh Perbedaan Lama Pengoperasian dan Kemiringan Dinding Bubu Terhadap Hasil Tangkapan Lobster (Panulirus sp.) di Perairan Argopeni
Kabupaten Kebumen. Journal of Fisheries Resources Utilization Management and Technology, 4(2): 83-92.

Kordi, M. G. H. 2010. Marikultur Prinsip dan Praktik Budidaya Laut. Lily Publisher.

Metusalach, Kasmiati, Fahrul, Ilham Jaya. 2014. Pengaruh Cara Penangkapan, Fasilitas Penangan Dan Cara Penanganan Ikan Terhadap Kualitas Ikan Yang Dihasilkan. Jurnal Ipteks Psp, 1(1): 40-52.

Nanholy. A, C. 2013. Evaluasi Alat Penangkap Ikan Pelagis yang Ramah Lingkungan di Perairan Maluku dengan Menggunakan Prinsip CCRF (Code of Conduct For Responsible Fisheries). Fakultas Perikanan dan Ilmu Kelautan Universitas Patimura Ambon. Jurnal Ilmu Hewani Tropika. 2(1): 1-11.

Peraturan Menteri Kelautan dan Perikanan Republik Indonesia Nomor 71/PERMEN-KP/2016. Tentang Jalur Penangkapan Ikan dan Penenmpatan Alat Penangkapan Ikan di Wilayah Pengelolaan Perikanan Negara Republik Indonesia. Jakarta.

Rusmilyansari. 2012. Inventarisasi Alat Tangkap Berdasarkan Kategori Status Penangkapan Ikan yang Bertanggungjawab di Perairan Tanah Laut. Fish Scientiae, 2(4):143-153.

Salfauz, Claudiya Radekna. 2015. Efektivitas Code of Conduct for Responsible Fisheries di Samudera Hindia Studi Kasus: Kerjasama Indonesia dan Australia Menanggulangi Illegal Unregulated Unreported (IUU) Fishing. Journal of International Relations, 1(2):57-63.

Setyasmoko, Tunjung Budi. 2015. Kesesuaian Teknis Rasio Gaya Apung (Bouyance Force) dan Gaya Tenggelam (Sinking Force) pada Pukat Cincin (Purse Seine) Tipe Waring di TPI Sendang Sikucing, Kabupaten Kendal. [SKRIPSI]. Universitas Diponegoro. Semarang.

Sima, A M., Yunasfi., Zulham, A.H. 2015. Identifikasi Alat tangkap Ikan Ramah Lingkungan di Desa Bagan Asahan Kecamatan Tanjung Balai. Universitas Sumatra Utara. Medan.

Suadela P. 2004. Analisis Tingkat Keramahan Lingkungan Unit Penangkapan Jaring Rajungan (Studi Kasus di Teluk Banten) [SKRIPSI]. Bogor: Fakultas Perikanan dan Ilmu Kelautam. Institut Pertanian Bogor. $111 \mathrm{hlm}$.

Sumardi, Zainal, M. Ali Sarong, Muhammad Nasir. 2014. Alat Penangkapan Ikan yang Ramah Lingkungan Berbasis Code of Conduct for Responsible Fisheries di Kota Banda Aceh. Agrisep, 15(2):10-18.

Wismaningrum, Kristina Endah Purna, Ismail, Aristi Dian Purnama Fitri. 2013. Analisis Finansial Usaha Penangkapan One Day Fishing dengan Alat Tangkap Multigear di Pelabuhan Perikanan Pantai (PPP) Tawang, Kabupaten Kendal. Journal of Fisheries Resources Utilization Management and Technology, 2(3):263-272.

\footnotetext{
${ }^{\circ}$ Copyright by Saintek Perikanan (Indonesian Journal of Fisheries Science and Technology), ISSN : 1858-4748
} 